\title{
UNREGISTERED MARRIAGE BETWEEN INDONESIAN CITIZENS AND FOREIGN CITIZENS WITH THE LEGAL PERSPECTIVE OF MARRIAGE IN INDONESIA
}

\author{
Muhammad Ngizzul Muttaqin \\ Program Studi Hukum Keluarga Islam Pascasarjana IAIN Tulungagung \\ Jl. Mayor Sujadi No. 46, Kabupaten Tulungagung, Provinsi Jawa Timur, 66221 \\ Email: muttaqinizzul19@gmail.com
}

\begin{abstract}
The practice of unregistered marriage between Indonesian citizens and foreign nationals always raises legal problems, both the law of marriage and the legal consequences of the marriage. This article aims to provide concrete legal solutions and steps to the practice of unregistered marriage between Indonesian citizens and foreign nationals. This study used literature research with qualitative descriptive methods, through a normative legal approach. The results show that unregistered marriage is a social symptom of modern society which always occurs in the practice of today's society. Although unregistered marriage is not specifically regulated in the practice of mixed marriages, it often occurs and must be anticipated. The solution is that there are three legal options that can be taken: first, if the person concerned is domiciled in Indonesia and intends to become an Indonesian citizen, then s/he can register the marriage with the employee who registers the marriage and performs the marriage certificate according to the provisions. Second, if the person concerned is living abroad but wants to become an Indonesian citizen, then s/he can take legal steps by registering the marriage and marriage certificate at the Indonesian Embassy. Third, if the person concerned is domiciled and wants to become a resident of a foreign country, then the person concerned must take the legal route that has been determined in that country. Thus, family law in Indonesia can be adaptive and responsive to the dynamics of social change.
\end{abstract}

Keywords: Unregistered marriage; Indonesian citizen; foreigner

\begin{abstract}
Abstrak: Praktik perkawinan siri antara warga negara Indonesia dan warga negara asing selalu memunculkan permasalahan hukum, baik hukum perkawinannya maupun akibat hukum dari perkawinannya. Artikel ini bertujuan memberikan solusi dan langkah hukum yang kongkrit terhadap praktik perkawinan siri antara warga negara Indonesia dan warga negara asing. Kajian ini menggunakan penelitian kepustakaan dengan metode deskriptif kualitatif, melalui pendekatan hukum normatif. Hasilnya menunjukkan bahwa nikah siri merupakan gejala sosial masyarakat modern yang selalu terjadi dalam praktik kehidupan masyarakat kini. Meskipun nikah siri secara khusus tidak diatur dalam praktik perkawinan campuran, namun peristiwa ini sering terjadi dan harus diantisipasi. Solusinya, ada tiga pilihan hukum yang bisa ditempuh: pertama, jika yang bersangkutan berkedudukan di Indonesia dan berniat menjadi warga Indonesia, maka bisa melakukan pencatatan perkawinan pada pegawai pencatat nikah dan melakukan itsbat nikah sesuai dengan ketentuan. Kedua, jika yang bersangkutan berkedukan di luar negeri namun menginginkan menjadi warga negara Indonesia, maka bisa melakukan langkah hukum dengan melakukan pencatatan perkawinan dan itsbat nikah di Kedutaan Besar Republik Indonesia. Ketiga, jika yang bersangkutan berkedudukan dan menginginkan menjadi penduduk negara asing, maka yang bersangkutan harus menempuh jalur hukum yang telah ditentukan dalam negara tersebut. Dengan demikian, hukum keluarga di Indonesia dapat adaptif dan responsif terhadap dinamika perubahan sosial.
\end{abstract}

Kata kunci: Perkawinan siri; warga negara Indonesia; warga negara asing 


\section{Introduction}

Marriage is one of the most important dimensions of life in human life in this world. ${ }^{1}$ Marriage is the method chosen by Allah SWT as a way for humans to get offspring, live together, and preserve their life. ${ }^{2}$ Each partner must be ready to play a positive role in realizing the goals of marriage. ${ }^{3}$ In the explanation of Law no. 1 of 1974 concerning Marriage that "marriage is a physical and spiritual bond between a man and a woman as husband and wife with the aim of forming a happy and eternal household based on the Almighty Godhead so that life in this world can reproduce well". ${ }^{4}$

Meanwhile, the provisions on family law have a very strong position in religion. ${ }^{5}$ Family law regulates the way of life of each family member. Where the family is the smallest group of a country. ${ }^{6}$ In the perspective of Islam, marriage has a very high religious meaning. This is because marriage is not just a legal event, but also a legal relationship

${ }^{1}$ Muhammad Ngizzul Muttaqin \& Nur Fadhilah, "Hak Ijbar Wali Tinjauan Maqashid Syari'ah Dan Antropologi Hukum Islam”, De Jure: Jurnal Hukum dan Syariah, Vol. 12, No. 1, 2020, p. 103.

${ }^{2}$ Ahmad Atabik dan Khoirotul Mudhiiah, "Pernikahan dan Hikmahnya Perspektif Hukum Islam”, Yudisia, Vol. 5, No. 2, 2014, p. 286.

${ }^{3}$ Zakyyah Iskandar, "Peran Kursus Pra Nikah dalam Mempersiapkan Pasangan Suami Istri Menuju Keluarga Sakinah", Al-Ahwal: Jurnal Hukum Keluarga Islam, Vol. 10, No. 1, 2017, p. 86.

${ }^{4}$ Syarifah Gustiawati \& Novia Lestari, "Aktualisasi Konsep Kafa'ah Dalam Membangun Keharmonisan Rumah Tangga", Mizan; Jurnal Ilmu Syariah, Vol. 4, No. 1, 2016, p. 34.

5 Anung Al Hamat, "Representasi Keluarga dalam Konteks Hukum Islam”, YUDISIA, Vol. 8, No. 1, 2017 , p. 139.

${ }^{6}$ Desi Asmaret, Alaiddin Koto, Afrizal, "Transformasi Hukum Keluarga Islam di Indonesia: Telaah Pemikiran Rifyal Ka'bah", Al-Ahwal: Jurnal Hukum Keluarga Islam, Vol. 12, No. 2, 2019, p. 146. between two people (male and female) in order to live together in a conjugal bond with the aim of building a family, avoiding adultery, protecting offspring, and maintaining peace of mind and family. ${ }^{7}$

Meanwhile, the provisions of family law in Indonesia, that through the provisions of Article 2 paragraph 1 of Law Number 1 of 1974 concerning Marriage that a legal marriage is a marriage which is carried out according to their respective laws and beliefs. Furthermore, Article 2 paragraph 2 of the Marriage Law confirms that every marriage is registered according to the prevailing laws and regulations. Thus every marriage must be registered with the Marriage Registration Officer (PPN) at the Office of Religious Affairs (KUA) for Muslims and at the Civil Registration Office for followers of religions other than Islam. This is further regulated in Government Regulation Number 9 of 1975 concerning Implementation of Law Number 1 of 1974 concerning Marriage. $^{8}$

This marriage registration aims to create administrative order and to protect the rights of the person carrying out the marriage. The registration of marriage is also proof that there has been a marriage.' However, the regulations in Indonesia regarding the registration of marriage are different from the regulations for the registration of

7 Winengan, "Politik Hukum Keluarga Islam di Aras Lokal: Analisis Terhadap Kebijakan Pendewasaan Usia Perkawinan di NTB", Al-Ahwal: Jurnal Hukum Keluarga Islam, Vol. 11, No. 1, 2018, p. 1.

${ }^{8}$ Rachmadi Usman, "Makna Pencatatan Perkawinan Dalam Peraturan Perundang-Undangan Di Indonesia", Jurnal Legislasi Indonesia, Vol. 14, No. 3, 2017, p. 270.

9 For further information, see Siti Musawwamah, "Akseptabilitas Regulasi Kriminalisasi Pelaku Nikah Sirri Menurut Pemuka Masyarakat Madura”, Al-Ihkam: Jurnal Hukum dan Pranata Sosial, Vol. 8, No. 2, 2013. 
marriage in other countries. As in Malaysia, which provides a fine of Ringgit 1000 and/ or imprisonment for a maximum of six months for those who marry without being registered. Meanwhile in Indonesia there are no specific regulations that impose sanctions on perpetrators of unregistered marriages. ${ }^{10}$ This sanction is still in the Draft Law on the material law of the Religious Courts in Marriage which is included in the $2010 \mathrm{draft}$ National Legislation Program (Prolegnas). Anyone who deliberately marries is not in the presence of a Marriage Registration Officer as referred to in Article 5 paragraph (1). ) shall be punished with a maximum fine of Rp. 6,000,000, (six million rupiah) or a maximum imprisonment of 6 (six) months". Meanwhile, Article 144 reads "Every person who engages in a mutah marriage as referred to in Article 39 is sentenced to imprisonment for a maximum of 3 (three years, and the marriage is canceled because of the law". ${ }^{11}$

Marriages not recorded as described above are usually called unregistered marriages. ${ }^{12}$ The practice of unregistered marriage and the lack of regulations regarding the registration of marriages in Indonesia are in some ways exploited by a handful of people. As quoted by Replubika.co.id that level II Putussibau West Kalimantan Immigration has recorded four foreign nationals (WNA) who have performed an unregistered marriage with Indonesian citizens (WNI) in the Indonesia-

\footnotetext{
${ }^{10}$ See Siti Nur Shoimah dan Dyah Ochtorina Susanti, "Urgensi Pencatatan Perkawinan (Perspektif Utilities)", Jurnal Rechtidee, Vol. 11, No. 2, 2016.

${ }^{11}$ Lihat, M. Nurul Irfan, "Kriminologi Poligami Dan Nikah Sirri”, Jurnal Al-'Adalah, Vol. X, No. 2, 2011.

12 Ahmad Badrut Tamam, "NIKAH SIRRI: Solusi Pernikahan Anak Di Bawah Umur Di Desa Petung, Panceng, Gresik", Jurnal Al-Ahwal, Vol. 3, No. 1, 2011, p. $42-43$.
}

Malaysia border area. ${ }^{13}$ Another case is the marriage between a man from China and a girl from Gorontalo which was apparently not registered. ${ }^{14}$ Many immigration officers also found cases of unregistered marriage when collecting data in the field. ${ }^{15}$

From several studies that the authors have found in this theme are: First, questioning the legality of unregistered marriage (istislahiyah analysis method), ${ }^{16}$ the findings in this study indicate that unregistered marriage is a marriage that does not use strong witnesses (marriage registration. Second, unregistered marriage from a legal perspective in Indonesia, ${ }^{17}$ The findings in this study indicate that unregistered marriage is a marriage that is not recognized by the state. Third, unregistered marriage in a review of theoretical law and the sociology of Indonesian Islamic law which states that legal certainty of unregistered marriage must go through clear and strong regulations through the marriage certificate in court. ${ }^{18}$

13 REPLUBIKA.co.id, "Empat WNA Diduga Menikah Siri Dengan Warga Kapuas Hulu”, Senin, 17 Juni, 2019, https://republika.co.id/berita/pt8fvc459/ empat-wna-diduga-menikah-siri-dengan-warga-kapuashulu, accessed on on 15 Juli 2020.

${ }^{14}$ Tim Editor, "WNA Asal Cina Nikah Siri Dengan Gadis Desa Di Gorontalo”, Kumparan, 8 Oktober, 2019, https://kumparan.com/banthayoid/wna-asal-cina-nikahsiri-dengan-gadis-desa-di-gorontalo-1s15AODNzsv/full, accessed on on 21 Juli 2020.

15 Madiani, "Kantor Imigrasi Temukan Banyak Warga Negara Asing Di Pangandaran Nikah Siri”, HarapanRakyat.Com, 5 Agustus, 2016, https://www. harapanrakyat.com/2016/08/kantor-imigrasi-temukanbanyak-warga-negara-asing-di-pangandaran-nikah-siri/, accessed on on 23 Juli 2020.

16 Sheila Fakhria, "Menyoal Legalitas Nikah Sirri (Analisis Metode Istislahiyah)", Al-Ahwal: Jurnal Hukum Keluarga Islam, Vol. 9, No. 2, 2016.

17 Supriyadi, "Perkawinan Sirri dalam Perspektif Hukum di Indonesia", YUDISIA: Jurnal Pemikiran Hukum dan Hukum Islam, Vol. 8, No. 1, 2017.

${ }^{18}$ Aidil Alfin, "Nikah Sirri dalam Tinjauan Hukum Teoritis dan Sosiologi Hukum Islam Indonesia", Al- 
From several studies that the author has revealed, the authors found differences in studies in the form of a discussion of the phenomenon of unregistered marriage carried out by Indonesian citizens and foreign citizens. In this incident, according to the author, there are two things behind it, first, because in a foreign country, unregistered marriage is a criminal act, while in Indonesia, unregistered marriage is not penalized. Second, the unregistered marriage in Indonesia is caused by the complicated requirements for registering marriages in Indonesia, which are different from those of the country of origin. ${ }^{19}$ This incident certainly intrigued the author to provide a theoretical analysis of the serial marriage between foreigners and Indonesian citizens. With the following research questions: First, what is the background of the unregistered marriage between Indonesian citizens and foreign citizens? Second, what are the steps and urgency of Indonesian marriage law in dealing with unregistered marriage cases between Indonesian citizens and foreign nationals?

In order to answer the research questions that have been described above. The author uses qualitative methods which is library research discussing the phenomenon of mixed marriage (Indonesians and foreigners) as a study. ${ }^{20}$ Considering that the research is purely literary in nature, the data in this research is obtained by conducting a study of various literatures consisting of books, journals, laws,

Manahij: Jurnal Kajian Hukum Islam, Vol. XI, No. 1, 2017.

${ }^{19}$ tirto.id, "Betapa Rumitnya Menikah Dengan Warga Negara Asing”, 13 September, 2017, https://tirto.id/ betapa-rumitnya-menikah-dengan-warga-negara-asingcwtq, accessed on on 19 Juli 2020.

20 Suharsimi Arikunto, Prosedur Penelitian Suatu Pendekatan Praktek, (Jakarta: Rineka Cipta, 2005), p. 10. and regulations, or the results of previous research that have a bearing on the object of discussion. ${ }^{21}$ The data collection method was carried out by using content analysis on the provisions of the law of marriage related to the concept of mixed marriage. ${ }^{22}$

\section{Mixed Marriage and Marriage Registration}

Mixed marriage is a marriage between two citizens, namely Indonesian citizens and foreign citizens who are married so that it has civil law consequences. In a mixed marriage between an Indonesian citizen and the foreign citizen concerned, the difference between the nationalities of the two parties is a matter of international civil law, namely which law will apply to the legal issues. ${ }^{23}$

Based on article 58 of Law No.1 of 1974, people who carry out mixed marriages can obtain citizenship according to the methods stipulated in the current citizenship law, namely Law Number 12 of 2006 concerning Citizenship of the Republic of Indonesia. Mixed marriages give rise to civil relations which are part of international civil law, because mixed marriages contain foreign elements, namely there are two different nationalities. This foreign element is what makes this relationship international, giving rise to international civil law relations. ${ }^{24}$

21 Mestika Zed, Metode Penelitian Kepustakaan, (Jakarta: Yayasan Obor Indonesia, 2007), p. 3.

22 Terkait dengan metode content analysis, lihat dalam C. R. Kothari, Research Methodology: Methods and Techniques, (New Delhi: New Age International Ltd. Publisher, 2004).

23 Herni Widanarti, "Akibat Hukum Perkawinan Campuran Terhadap Harta Perkawinan (Penetapan Pengadilan Negeri Denpasar No: 536/Pdt.P/2015/ PN.Dps.)", Diponegoro Private Law Review, Vol. 2, No. 2, 2018, p. 162.

24 see, Gerdha Prastica Pangestu, "Studi Tentang Perkawinan Campuran Antara Warga Negara Malaysia- 
Getting married to create a family while preserving offspring is a right for everyone. Article 28 B Paragraph 1 of the 1945 Constitution states that all people have the right to form a family and their offspring through a legal marriage. Meanwhile, Article 10 of Law Number 39 Year 1999 concerning Human Rights states that marriage is a part of human rights. This implies that a marriage cannot be forced, it can only take place according to the wishes of the two candidates and must be in accordance with the applicable laws and regulations. ${ }^{25}$

One of the marital events described above is mixed marriage. In the third part of chapter XII of Law Number 1 Year 1974 it has explained and regulated mixed marriages in Articles 57 to 62. Article 57 states that the meaning of mixed marriage is marriage between two people who are in Indonesia, but have different nationalities and subject to different legal rules due to differences in nationality.

Marriage registration is a rule that contains mashlahah and benefits and is a form of announcement to the public, ${ }^{26}$ because the things that follow are very important events in the continuity of human life. ${ }^{27}$ This

Indonesia", Gloria Yuris Jurnal Hukum, Vol. 3, No. 1, 2014.

25 Rahmat Fauzi, "Dampak Perkawinan Campuran Terhadap Status Kewarganegaraan Anak Menurut Hukum Positif Indonesia”, Soumatera Law Review, Vol. 1, No. 1, 2018, p. 159.

${ }^{26}$ Khoiruddin Nasution, "Pencatatan Sebagai Syarat Atau Rukun Perkawinan: Kajian Perpaduan Tematik dan Holistik", Musawa: Jurnal Studi Gender dan Islam, Vol. 12, No. 2, 2013, p. 184.

${ }^{27}$ Regard to the concepts of mashlahah and benefits, see Iffatin Nur dan Muhammad Ngizzul Muttaqin, "Reformulating The Concept of Maslahah: From A Textual Confinement Toward A Logic Determination", Justicia Islamica: Jurnal Kajian Hukum dan Sosial, Vol. 17, No. 1, 2020. regulation regarding marriage registration is intended so that marriages are not misused to fulfill personal needs and harm other parties. The rules that have been described in the General Rules of Law Number 1 of 1974 concerning the principles of legal marriage, all people have the obligation to register their marriage. This aims to provide further legal certainty, such as child birth, inheritance and others. The obligation to register a marriage as regulated in Article 2 Paragraph 2 of the Marriage Law is not only a mere administrative requirement, but also a requirement of legality. ${ }^{28}$

So that in this condition, marriage registration is something that is very urgent nowadays. $^{29}$ Because the realization of marriage registration can minimize actions that are detrimental to one of the parties. Thus, everyone should comply with the legal provisions contained in Law Number 1 of 1974 concerning marriage (especially regarding marriage registration).

Marriage law in Indonesia is basically administrative in nature. Therefore it does not determine the legality of a marriage. Although there are differences of opinion among legal experts, whether it is mandatory or not regarding the registration of marriages, enforcement of this rule returns to the government's firmness in protecting the rights of its citizens. ${ }^{30}$ Given the importance of

28 Dwi Arini Zubaidah, "Pencatatan Perkawinan Sebagai Perlindungan Hukum dalam Perspektif Maqashid Asy-Syariah", Al-Ahwal, Vol. 12, No. 1, 2019, p. 18.

29 Nastangin, "Tinjauan Folosofis (Pasal 2 Ayat 2 Undang-Undang Perkawinan Nomor 1 Tahun 1974 Tentang Pencatatan Perkawinan)", Mahakim: Journal of Islamic Family Law, Vol. 2, No. 1, 2018, p. 23.

${ }^{30}$ Marwin, "Pencatatan Perkawinan dan Syarat Sah Perkawinan dalam Tatanan Konstitusi”, ASAS: Jurnal Hukum Ekonomi Syariah, Vol. 6, No. 2, 2014, p. 112. 
marriage registration, namely for the sake of legal certainty and guarantee, in this condition the government takes part in law enforcement, so that there are no more marital cases that will harm either party. ${ }^{31}$ Meanwhile, from the State's point of view, marriage registration is obligatory within the framework of the state's function to guarantee protection, guarantee, enforcement and fulfillment of human rights which are the responsibility of the State and must be implemented in accordance with the principles of the state democratic law which are regulated and set forth in statutory regulations. ${ }^{32}$

\section{Comparative Study of Marriage Registration Rules between Indonesia and Several Countries}

Marriage registration is a very important thing and cannot be ruled out because it involves the interests of many people. The urgency of marriage registration is not only an administrative requirement, but is an effort to benefit all parties and have strong legal force. ${ }^{33}$ This aims to create justice that not only benefits one party, but also benefits the people around them. Meanwhile, the benefit of marriage registration is in accordance with the legal objective, namely to provide the maximum benefit for the community. ${ }^{34}$

${ }^{31}$ Itsnatul Lathifah, "Pencatatan Perkawinan: Melacak Akar Budaya Hukum dan Respon Masyarakat Indonesia Terhadap Pencatatan Perkawinan", Al-Mazahib: Jurnal Pemikiran Hukum, Vol. 3, No. 1, 2015, p. 54.

32 Neng Djubaidah, Pencatatan Perkawinan dan Perkawinan Tidak Dicatat Menurut Hukum Tertulis di Indonesian dan Hukum Islam, (Jakarta: Sinar Grafika, 2012), p. 32.

${ }^{33}$ Novita Lestari, "Problematika Hukum Perkawinan Di Indonesia", Jurnal Ilmiah Mizani: Wacana Hukum, Ekonomi Dan Keagamaan, Vol. 4, No. 1, 2017, p. 146.

34 See Nenan Julir, "Pencatatan Perkawinan Di Indonesia Perspektif Ushul Fikih", Jurnal Ilmiah Mizani:
Some countries impose an obligation for their people to register their marriage contract at a designated government agency. Although in the implementation in several countries there are differences. As in the State of Jordan which provides a fine of more than 100 Dinars when a person does not register his marriage at the office or authorized officer. This provision is regulated in Article 17 Paragraph 3 of the Law of Family Right. Furthermore, if the registration is not officially carried out by an authorized officer, the officer will receive a penalty and / or a fine and / or dismissal from his position, as stipulated in Article 279 of the Jordanian Criminal Code. ${ }^{35}$

Meanwhile, in the State of Pakistan, a marriage contract that is not registered at the authorized institution will be subject to a maximum prison sentence of three months and a fine of 1000 Rupees. This provision is regulated in Article 5 of the Muslim Family Law Ordinance 1961. Whereas Malaysia, for residents who are getting married and within six months of not registering their marriage with the competent authority, they will be punished with a fine of 1000 Ringgit and/or a maximum imprisonment of six months. . This provision is regulated in the Family Law Law 1984 Article $33 .{ }^{36}$

The last country is Brunei Darussalam, where this country provides a rule that every marriage contract may only be carried out if it is led by a person appointed by the Sultan and given the authority to lead the implementation

Wacana Hukum, Ekonomi Dan Keagamaan, Vol. 4, No. 1, 2017.

${ }^{35}$ Khoiruddin Nasution, Hukum Keluarga Di Dunia Muslim, (Yogyakarta: Academia, 2011), p. 45.

36 See M. Atho Mudzhar, "Hukum Keluarga Di Pakistan (Antara Islamisasi Dan Tekanan Adat)", Jurnal Al-'Adalah, Vol. 12, No. 1, 2014. 
of the marriage contract. ${ }^{37}$ Several of Brunei Darussalam's 2000 family law laws stipulate several things, including article 2 which stipulates that it is not permissible to enter into a marriage contract before obtaining permission from a marriage registration official. Article 3 states that a guardian can marry and lead the marriage contract only in front of an authorized marriage registrar. As well as what it says in Article 37 that whoever leads the marriage contract without obtaining permission from the sultan, will be subject to a fine of 2000 Ringgit and/or a maximum imprisonment of six months. ${ }^{38}$

\section{Marriage Issues between Indonesian Citizens and Foreigners from the Perspective of Marriage Law in Indonesia}

Mixed marriage is a marriage between two people who are subject to legal procedures in Indonesia which is carried out by two people with different nationalities called mixed marriage. In the provisions, this mixed marriage must be carried out based on the conditions of the marriage, in accordance with Article 2 of Law Number 1 Year 1974.

In the laws and regulations in Indonesia that regulate marriage, including, 1. Law Number 1 of 1974 concerning Marriage, 2. Government Regulation Number 9 of 1975 concerning Implementation of Law Number 1 of 1974,3 . Presidential Instruction Number 1 Year 1991 concerning Dissemination of

37 Lilis Hidayati Yuli Astutik dan Muhammad Ngizzul Muttaqin, "Positifikasi Hukum Keluarga Di Dunia Muslim Melalui Pembaharuan Hukum Keluarga”, Islamika: Jurnal Ilmu-Ilmu Keislaman, Vol. 20, No. 1, 2020, p. 61.

38 A. Intan Cahyani, "Hukum Keluarga Islam Di Brunei Darussalam”, Jurnal Al-Qadhau, Vol. 2, No. 2, 2015.
Compilation of Islamic law as regulations for those who are Muslim, 4. Law Number 16 of 2019 concerning Amendments to Law Number 1 of 1974 concerning Marriage.

With the issue of citizenship, Article 58 provides that people who are married to mixed marriages can obtain citizenship from their husband or wife and can also lose their citizenship. This is in accordance with the procedures stipulated in the Citizenship Law in force in Indonesia. This is closely related to the Citizenship Law which provides an explanation of how to obtain and lose Indonesian citizenship. In addition, this Article greatly affects the Immigration Law in terms of granting residence permits for wives or husbands who are Indonesian citizens. ${ }^{39}$

Furthermore, if related with the previous Article which regulates marriages outside Indonesia, namely Article 56 Paragraph 1 which states that: "Marriage which is carried out outside Indonesia between two Indonesian citizens or an Indonesian citizen and a foreign citizen is legal if it is carried out according to law. which applies in the country where the marriage was carried out and for Indonesian citizens it does not violate the provisions of this Law".

Furthermore, in the context of a series of mixed marriages in Indonesia, this action is an action that is bound by law in Indonesia. Article 2 of the Marriage Law states that "Marriage is legal, if it is carried out according to the law of each religion and belief. Every marriage is recorded according to the prevailing laws and regulations". Meanwhile, the basic concept of mixed marriage is

39 Jazim Hamidi dan Charles Cristian, Hukum Keimigrasian Bagi Orang Asing di Indonesia, (Jakarta: Sinar Grafika, 2015), p. 56. 
regulated in Articles 57-63 of the Marriage Law, which states "What is meant by mixed marriage in this law is a marriage between two people who in Indonesia are subject to different laws, because of differences in nationality and one of the parties is a national. Indonesia". ${ }^{40}$

Meanwhile, the registration of marriage for those who are Muslim is in accordance with Article 2 Paragraph 2 of Government Regulation Number 9 of 1975, “The registration of marriages of those who carry out their marriage according to the Islamic religion is carried out by Registrar as referred to in Law Number 32 of 1954 concerning Registration. Marriage, Divorce and Reconciliation". ${ }^{41}$ While in Article 5 of Compilation of Islamic Law". In order to ensure orderliness of marriage for the Muslim community, every marriage must be recorded. 2. The registration of such marriages as referred to in paragraph (1) shall be carried out by the Registrar of Marriages as regulated in Law Number 22 Year 1946 jo Law Number 32 Year 1954.”42

In the case of unregistered marriages committed by Indonesian citizens and foreign citizens, in the author's view there are two legal steps that must be taken:

1. If the bride and groom get married in Indonesia

If the bride and groom are Muslims, then in the context of registration of marriage, they submit a marriage certificate and then submit a marriage certificate to the Religious Court in accordance with the domicile area.

\footnotetext{
40 Undang-undang Nomor 1 Tahun 1974 Tentang Perkawinan.

${ }^{41}$ Peraturan Pemerintah Nomor 9 Tahun 1975.

${ }^{42}$ Undang-undang Nomor 22 Tahun 1946 jo Undangundang Nomor 32 Tahun 1954.
}

This is in accordance with the mandate of Article 7 of the Compilation of Islamic Law, "1. Marriage can only be proven by a Marriage Certificate made by a Marriage Registration Officer, 2. In the event that a marriage cannot be proven by a Marriage Certificate, the marriage certificate can be submitted to the Religious Court, 3. The marriage certificate which can be submitted to the Religious Court is limited to matters that in connection with: a. The existence of marriage in the context of divorce settlement, b. Loss of marriage certificate, c. There are doubts about whether or not one of the conditions of marriage is valid, $\mathrm{d}$. The existence of marriages that occurred before the enactment of Law No. 1 of 1974, e. Marriages that are carried out by those who do not have a marriage impediment according to Law Number 1 of 1974, 4. Those who have the right to apply for a marriage certificate are husband or wife, their children, marriage guardians and parties with an interest in the marriage". 43

2. If the bride and groom are married abroad The registration of marriages held overseas is regulated in Article 56 Paragraph 2 of the Marriage Law, "Within 1 (one) year after the husband and wife return to the territory of Indonesia, proof of their marriage must be registered at the Marriage Registration Office where they live."

In addition, Article 4 of Law Number 23 of 2006 concerning Population Administration regulates that regarding the obligations for Indonesian citizens who are abroad to, "Indonesian citizens who are outside the territory of the Unitary State

43 Undang-undang Nomor 1 Tahun 1974 Tentang Perkawinan. 
of the Republic of Indonesia are obliged to report Population Events and Important Events that experienced to the local state Civil Registration Implementing Agency and/or to a Representative of the Republic of Indonesia by fulfilling the requirements required in Population Registration and Civil Registration". Important events referred to in Law Number 23 of 2006 are defined in Article 1 point 17 of the General Provisions, namely "Important events are events experienced by a person including birth, death, birth, marriage, divorce, recognition of children, legalization of children, adoption of children, change of name and change of citizenship status". ${ }^{44}$

In the condition when the unregistered marriage is carried out abroad, then the person concerned commits the marriage ceremony abroad. This is based on Law Number 48 of 2009 concerning Judicial Power Article 60B and Supreme Court Decree Number 084/KMA/SK/V/2011 concerning Permits to Determine Marriage (Isbat Nikah) at the Representative Office of the Republic of Indonesia. This regulation provides legal protection and legal certainty for all countries located everywhere.

\section{Registration of Marriage by Indonesian Citizens and Foreign Citizens: Between Legal Protection and State Protection Guarantee}

Regulations concerning the importance of marriage registration have important meanings, first, marriage registration from the perspective of the State has a function as an effort of the State to provide protection,

${ }^{44}$ Undang-undang Nomor 23 Tahun 2006 tentang Administrasi Kependudukan. enforcement and fulfillment of human rights for married couples. Where this goal is the responsibility of the State and must be carried out in accordance with the principles of the rule of law which are regulated through statutory regulations and not contrary to constitutional provisions. Second, the registration of a marriage is an administrative requirement established by the State as an effort to create a marriage based on law and guarantee its legal consequences. This administrative requirement is proven by authentic evidence, so that it can provide protection and services by the State in the context of fulfilling the rights arising from the existence of the marriage. ${ }^{45}$

Marriage registration as evidenced by the existence of a marriage book is intended to ease the burden of proof. ${ }^{46}$ The marriage book, which is the result of the marriage registration, is then used to provide evidence of the origin of the child, inheritance and so on. On the other hand, if the marriage is not registered with the child, it creates a legal problem due to the marriage. Legal issues arising from marriage are not recorded not only in the legal status of marriage in the State, but also regarding legal protection for spouses (wives), children, and everything caused by marriage.

The impact of not recording a marriage results in unclear marital status, even if the child born from the marriage is not registered as a legal child legally. Meanwhile, if there is a divorce in the future, then legal divorce in court also cannot be carried out without proof

45 Harpani Matnuh, "Perkawinan Dibawah Tangan dan Akibat Hukumnya Menurut Hukum Perkawinan Nasional", Jurnal Pendidikan Kewarganegaraan, Vol. 6, No. 11, 2016, p. 907.

46 Lihat dalam, Nunung Rodliyah, "Pencatatan Pernikahan dan Akta Nikah Sebagai Legalitas Pernikahan Menurut Kompilasi Hukum Islam”, Pranata Hukum, Vol. 8, No. 1, 2013. 
of marriage registration. Another impact also causes loss of civil rights for wives and children, because their civil rights are not protected by law. This is because a marriage that is not recorded will not cause a legal relationship between husband, wife and children. ${ }^{47}$

Meanwhile, the Islamic Law Compilation (KHI) considers that the registration of marriage is an administrative requirement. As a result, if the marriage is not registered, the marriage will not have strong legal force. The impact that arises is if one party neglects its obligations, the other party cannot take legal remedies. This is due to the absence of valid evidence of the marriage which he took place. ${ }^{48}$

Another very big effect of marriage registration is the existence of a marriage book which is authentic evidence of a valid marriage. ${ }^{49}$ This evidence can last forever as long as it is there. However, it is different from evidence in the form of testimony, only valid as long as the witness is still alive. As an evidence, marriage registration also has implications for rights and obligations protected by law. Such as the obligation to provide for his wife, child support, inheritance, and children's education.

Marriage registration (including mixed marriages) is a very urgent legal effort nowadays. This is due to the many cases of neglect of children and wives, divorce, domestic violence, contract marriages, and one of the causes is unregistered marriages. In order to overcome

${ }^{47}$ Dahlia Haliah Ma'u, "Nikah Sirri dan Perlindungan Hak-Hak Wanita dan Anak (Analisis dan Solusi dalam Bingkai Syari'ah)", al-ahkam: Jurnal Ilmu Syariah dan Hukum, Vol. 1, No. 1, 2016.

${ }^{48}$ Kompilasi Hukum Islam.

49 Endang Ali Ma’sum, "Pernikahan Yang Tidak Dicatatkan dan Problematikanya", Musawa: Jurnal Studi Gender dan Islam, Vol. 12, No. 2, 2013, p. 203. this problem, through the provisions in Article 2 Paragraph 2 of Law Number 1 of 1974 and Government Regulation Number 9 of 1975 , the Indonesian government wants to provide protection for the community. Some of the purposes and benefits of marriage registration are:

1. Creating legal guarantees and certainty as well as the legality of the status of husband and wife and their children born from this marriage.

2. Ensuring and facilitating the bureaucracy and continuity (process) of obtaining birth certificates for children by including the names of both parents.

3. Ensuring the existence of rights and obligations.

4. Guaranteed welfare of children and guaranteed inheritance rights for children born from this marriage.

In this condition, the registration of marriages (including mixed marriages) is not only considered an administrative part. ${ }^{50}$ However, marriage registration should have clear and binding legal force and as a determinant of whether a marriage is legal or not. This includes mixed marriages, which are marriages conducted by two people with different nationalities.

\section{Conclusion}

Unregistered marriage is a social phenomenon that always occurs in the practice of modern society. Indonesian family law must respond to these social symptoms. However,

\footnotetext{
50 See Nur Anisah, "Pelaksanaan Perkawinan Campuran di KUA Tahunan, Jepara dalam Tinjauan Undang-Undang Perkawinan Indonesia”, ISTI'DAL: Jurnal Studi Hukum Islam, Vol. 5, No. 1, 2018.
} 
unregistered marriage is not specifically regulated in the practice of mixed marriages (between Indonesians and foreigners). It occurs frequently and considers legal status. In the case of a unregistered marriage occurred between Indonesian and foreign citizens, then there are three legal options that must be taken: first, if the person concerned is domiciled in Indonesia and intends to become an Indonesian citizen, then s/he can register the marriage with the employee who registers the marriage and performs itsbat the marriage in accordance with the provisions. Second, if the person concerned is living abroad but wants to become an Indonesian citizen, s/he can take legal steps by registering his marriage and marriage certificate at the Indonesian Embassy. Third, if the person concerned is domiciled and wants to become a resident of a foreign country, then the person concerned must take the legal route that has been determined in that country.

The urgency of the legal solution to mixed-unregistered marriages is to provide legal certainty for both parties and their offspring as well as to avoid the smuggling of citizens' laws which could be a problem in the survival of the state. Therefore, it is hoped that law enforcers must be more selective in reading the case of mixed and unmarried marriages.

\section{References}

Al Hamat, Anung. "Representasi Keluarga dalam Konteks Hukum Islam.” Yudisia, Vol. 8, No. 1, 2017.

Alfin, Aidil. "Nikah Siri dalam Tinjauan Hukum Teoritis dan Sosiologi Hukum Islam Indonesia." Al-Manahij: Jurnal Kajian Hukum Islam, Vol. XI, No. 1, 2017.
Anisah, Nur. "Pelaksanaan Perkawinan Campuran di KUA Tahunan, Jepara dalam Tinjauan Undang-Undang Perkawinan Indonesia." Istidal: Jurnal Studi Hukum Islam, Vol. 5, No. 1, 2018.

Arikunto, Suharsimi. Prosedur Penelitian Suatu Pendekatan Praktek, Jakarta: Rineka Cipta, 2005.

Asmaret, Desi, Alaiddin Koto, Afrizal. "Transformasi Hukum Keluarga Islam di Indonesia: Telaah Pemikiran Rifyal Ka'bah." Al-Ahwal: Jurnal Hukum Keluarga Islam, Vol. 12, No. 2, 2019.

Astutik, Lilis Hidayati Yuli dan Muhammad Ngizzul Muttaqin. "Positifikasi Hukum Keluarga Di Dunia Muslim Melalui Pembaharuan Hukum Keluarga." Islamika: Jurnal Ilmu-Ilmu Keislaman, Vol. 20, No. 1, 2020.

Atabik, Ahmad dan Khoirotul Mudhiiah. "Pernikahan dan Hikmahnya Perspektif Hukum Islam.” Yudisia, Vol. 5, No. 2, 2014.

Cahyani, A. Intan. "Hukum Keluarga Islam Di Brunei Darussalam." Jurnal Al-Qadau, Vol. 2, No. 2, 2015.

Djubaidah, Neng Pencatatan Perkawinan dan Perkawinan Tidak Dicatat Menurut Hukum Tertulis di Indonesian dan Hukum Islam, Jakarta: Sinar Grafika, 2012.

Fakhria, Sheila. "Menyoal Legalitas Nikah Siri (Analisis Metode Istislahiyah)." Al-Ahwal: Jurnal Hukum Keluarga Islam, Vol. 9, No. 2, 2016.

Fauzi, Rahmat. "DampakPerkawinan Campuran Terhadap Status Kewarganegaraan Anak Menurut Hukum Positif Indonesia." Soumatera Law Review, Vol. 1, No. 1, 2018. 
Gustiawati, Syarifah \& Novia Lestari. "Aktualisasi Konsep Kafa'ah Dalam Membangun Keharmonisan Rumah Tangga." Mizan; Jurnal Ilmu Syariah, Vol. 4, No. 1, 2016.

Hamidi, Jazim dan Charles Cristian. Hukum Keimigrasian Bagi Orang Asing di Indonesia, Jakarta: Sinar Grafika, 2015.

Irfan, M. Nurul. "Kriminologi Poligami Dan Nikah Siri." Jurnal Al-'Adalah, Vol. X, No. 2, 2011 .

Iskandar, Zakyyah Iskandar. "Peran Kursus Pra Nikah dalam Mempersiapkan Pasangan Suami Istri Menuju Keluarga Sakinah.”, Al-Ahwal: Jurnal Hukum Keluarga Islam, Vol. 10, No. 1, 2017.

Julir, Nenan. "Pencatatan Perkawinan Di Indonesia Perspektif Ushul Fikih.” Jurnal Ilmiah Mizani: Wacana Hukum, Ekonomi Dan Keagamaan, Vol. 4, No. 1, 2017.

Kompilasi Hukum Islam.

Kothari, C. R. Research Methodology: Methods and Techniques, New Delhi: New Age International Ltd. Publisher, 2004.

Lathifah, Itsnaatul. "Pencatatan Perkawinan: Melacak Akar Budaya Hukum dan Respon Masyarakat Indonesia Terhadap Pencatatan Perkawinan." Al-Mazahib: Jurnal Pemikiran Hukum, Vol. 3, No. 1, 2015.

Lestari, Novita. "Problematika Hukum Perkawinan di Indonesia." Jurnal Ilmiah Mizani: Wacana Hukum, Ekonomi Dan Keagamaan, Vol. 4, No. 1, 2017.

Ma’sum, Endang Ali. "Pernikahan Yang Tidak Dicatatkan dan Problematikanya." Musawa: Jurnal Studi Gender dan Islam, Vol. 12, No. 2, 2013.
Ma'u, Dahlia Haliah. "Nikah Siri dan Perlindungan Hak-Hak Wanita dan Anak (Analisis dan Solusi dalam Bingkai Syari'ah)." al-Ahkam: Jurnal Ilmu Syariah dan Hukum, Vol. 1, No. 1, 2016.

Madiani. "Kantor Imigrasi Temukan Banyak Warga Negara Asing di Pangandaran Nikah Siri." HarapanRakyat.Com, 5 Agustus, 2016,https:/www.harapanrakyat. com/2016/08/kantor-imigrasitemukan-banyak-warga-negara-asing-dipangandaran-nikah-siri/, accessed on on 23 Juli 2020.

Marwin. "Pencatatan Perkawinan dan Syarat Sah Perkawinan dalam Tatanan Konstitusi." Asas: Jurnal Hukum Ekonomi Syariah, Vol. 6, No. 2, 2014.

Matnuh, Harpani "Perkawinan Dibawah Tangan dan Akibat Hukumnya Menurut Hukum Perkawinan Nasional.” Jurnal Pendidikan Kewarganegaraan, Vol. 6, No. 11, 2016.

Mudzhar, M. Atho. "Hukum Keluarga di Pakistan (Antara Islamisasi dan Tekanan Adat)." Jurnal Al-'Adalah, Vol. 12, No. 1, 2014.

Musawwamah, Siti. "Akseptabilitas Regulasi Kriminalisasi Pelaku Nikah Siri Menurut Pemuka Masyarakat Madura.", Al-Ihkam: Jurnal Hukum dan Pranata Sosial, Vol. 8, No. 2, 2013.

Muttaqin, Muhammad Ngizzul \& Nur Fadhilah. "Hak Ijbar Wali Tinjauan Maqashid Syari'ah dan Antropologi Hukum Islam." De Jure: Jurnal Hukum dan Syariah, Vol. 12, No. 1, 2020.

Nastangin. "Tinjauan Folosofis (Pasal 2 Ayat 2 Undang-Undang Perkawinan Nomor 1 Tahun 1974 Tentang Pencatatan 
Perkawinan).” Mahakim: Journal of Islamic Family Law, Vol. 2, No. 1, 2018.

Nasution, Khoiruddin. "Pencatatan Sebagai Syarat Atau Rukun Perkawinan: Kajian Perpaduan Tematik dan Holistik." Musawa: Jurnal Studi Gender dan Islam, Vol. 12, No. 2, 2013.

Nasution, Khoiruddin. Hukum Keluarga di Dunia Muslim, Yogyakarta: Academia, 2011.

Nur, Iffatin dan Muhammad Ngizzul Muttaqin. "Reformulating The Concept of Maslahah: From A Textual Confinement Toward A Logic Determination.” Justicia Islamica: Jurnal Kajian Hukum dan Sosial, Vol. 17, No. 1, 2020.

Pangestu, Gerdha Prastica, "Studi Tentang Perkawinan Campuran Antara Warga Negara Malaysia-Indonesia." Gloria Yuris Jurnal Hukum, Vol. 3, No. 1, 2014.

Peraturan Pemerintah Nomor 9 Tahun 1975.

REPUBLIKA.co.id. "Empat WNA Diduga Menikah Siri Dengan Warga Kapuas Hulu." Senin, 17 Juni, 2019, https:// republika.co.id/berita/pt8fvc459/empatwna-diduga-menikah-siri-dengan-wargakapuas-hulu, accessed on on 15 Juli 2020.

Rodliyah, Rodliyah. "Pencatatan Pernikahan dan Akta Nikah Sebagai Legalitas Pernikahan Menurut Kompilasi Hukum Islam.” Pranata Hukum, Vol. 8, No. 1, 2013.

Shoimah, Siti Nur dan Dyah Ochtorina Susanti. "Urgensi Pencatatan Perkawinan (Perspektif Utilities).” Jurnal Rechtidee, Vol. 11, No. 2, 2016.

Supriyadi. "Perkawinan Siri dalam Perspektif Hukum di Indonesia." Yudisia: Jurnal
Pemikiran Hukum dan Hukum Islam, Vol. 8, No. 1, 2017.

Tamam, Ahmad Badrut. "NIKAH SIRI: Solusi Pernikahan Anak Di Bawah Umur Di Desa Petung, Panceng, Gresik.” Jurnal Al-Ahwal, Vol. 3, No. 1, 2011.

Tim Editor. "WNA Asal Cina Nikah Siri Dengan Gadis Desa Di Gorontalo.” Kumparan, 8 Oktober, 2019, https:// kumparan.com/banthayoid/wna-asalcina-nikah-siri-dengan-gadis-desa-digorontalo-1s15AODNzsv/full, accessed on on 21 Juli 2020.

tirto.id. "Betapa Rumitnya Menikah Dengan Warga Negara Asing.” 13 September, 2017, https://tirto.id/betapa-rumitnyamenikah-dengan-warga-negara-asingcwtq, accessed on on 19 Juli 2020.

Undang-undang Nomor 1 Tahun 1974 Tentang Perkawinan.

Undang-undang Nomor 1 Tahun 1974 Tentang Perkawinan.

Undang-undang Nomor 22 Tahun 1946 jo Undang-undang Nomor 32 Tahun 1954.

Undang-undang Nomor 23 Tahun 2006 tentang Administrasi Kependudukan.

Usman, Rachmadi. "Makna Pencatatan Perkawinan Dalam Peraturan PerundangUndangan di Indonesia." Jurnal Legislasi Indonesia, Vol. 14, No. 3, 2017 ,

Widanarti, Herni. "Akibat Hukum Perkawinan Campuran Terhadap Harta Perkawinan (Penetapan Pengadilan Negeri Denpasar No: 536/Pdt.P/2015/ PN.Dps.)." Diponegoro Private Law Review, Vol. 2, No. 2, 2018.

Winengan. "Politik Hukum Keluarga Islam di Aras Lokal: Analisis Terhadap Kebijakan 
Pendewasaan Usia Perkawinan di NTB.” Al-Ahwal: Jurnal Hukum Keluarga Islam, Vol. 11, No. 1, 2018.

Zed, Mestika. Metode Penelitian Kepustakaan, Jakarta: Yayasan Obor Indonesia, 2007.
Zubaidah, Dwi Arini. "Pencatatan Perkawinan Sebagai Perlindungan Hukum dalam Perspektif Maqashid Asy-Syari'ah.” Al-Ahwal, Vol. 12, No. 1, 2019. 